\title{
Life Cycle Cost Assessment of Electric Vehicles: A Review and Bibliometric Analysis
}

\author{
Bamidele Victor Ayodele *(1) and Siti Indati Mustapa * \\ Institute of Energy Policy and Research, Universiti Tenaga Nasional, Jalan IKRAM-UNITEN, \\ Kajang 43000, Selangor, Malaysia \\ * Correspondence: ayodelebv@gmail.com (B.V.A.); indati@uniten.edu.my (S.I.M.)
}

Received: 18 December 2019; Accepted: 11 January 2020; Published: 19 March 2020

check for updates

\begin{abstract}
The transportation sector has been reported as a key contributor to the emissions of greenhouse gases responsible for global warming. Hence, the need for the introduction of electric vehicles (EVs) into the transportation sector. However, the competitiveness of the EVs with the conventional internal combustion engine vehicles has been a bone of contention. Life cycle cost analysis (LCCA) is an important tool that can be employed to determine the competitiveness of a product in its early stage of production. This review examines different published articles on LCCA of EVs using Scopus and Web of Science databases. The time trend of the published articles from 2001 to 2019 was examined. Moreover, the LCC obtained from the different models of EVs were compared. There was a growing interest in research on the LCC of EVs as indicated by the upward increase in the number of published articles. A variation in the LCC of the different EVs studied was observed to depend on several factors. Based on the LCC, EVs were found not yet competitive with conventional internal combustion engine cars due to the high cost of batteries. However, advancement in technologies with incentives could bring down the cost of EV batteries to make it competitive in the future.
\end{abstract}

Keywords: life cycle cost; electric vehicle; systematic review; bibliometric analysis

\section{Introduction}

The transportation sector is one of the highest contributors to greenhouse gas emissions [1,2]. Studies have shown that about $28 \%$ of the total carbon dioxide emissions originated from the transportation sector [3]. The demand for internal combustion engine cars is on the increase, hence, will naturally translate to the emissions of more carbon dioxide in the future [4]. The quest to address the challenges of reducing carbon dioxide emissions from internal combustion engine vehicles has given rise to various alternative vehicles powered using low carbon fossil fuel such as compressed natural gas, liquid natural gas, and liquid petroleum gas [5,6]. Moreover, advances in biofuel production and utilization in the internal combustion engine vehicles are on point to help mitigate the amount of $\mathrm{CO}_{2}$ emission from the transportation sector $[7,8]$. Although, the life cycle assessment of the vehicles powered by these low carbon fuels revealed that the equivalent $\mathrm{CO}_{2}$ emission is comparatively lower compared to the internal combustion engine vehicles $[9,10]$. However, the challenges of $\mathrm{CO}_{2}$ emissions still persist even with the low-carbon fuel source vehicles [11,12]. In view of this, research efforts have geared towards zero emissions alternative vehicles such as battery electric vehicles, and hydrogen fuel cell vehicles [13]. As a result, as of global awareness on the reduction of greenhouse gas emission in transportation, the global demand for electric vehicles has been on the rise, as shown in Figure 1a. As of 2018, over two million electric cars have been sold globally compared to a few thousand that were sold in 2010 [14]. Specifically, the European Union has also experienced a high volume of EV inclusion in the transportation sector over the years, as shown in Figure $1 b$. 
The increase in the demand for electric vehicles can be hinged on the various policies formulated to make it affordable to people. As shown in Figure 2, the various policies formulated with respect to the electric vehicle include regulation, incentive and target. The electric vehicle regulation covers zero-emission vehicles and fuel economy standards. In addition, fiscal incentives were also incorporated to encourage buyers. Besides policies related to the electric vehicles, these policies (regulation and incentives) were also formulated for the production of the chargers. The regulation policy covers the building of the charging station while fiscal incentives were also made available for the building. Some of these regulations are being championed by the European Union, Canada, China, India and the United States [14].

Electric vehicles that are powered by electricity are usually driven by electric motors coupled with rechargeable batteries [15]. There exist different types of electric vehicles depending on the power source [16]. The types of electric vehicles include battery electric vehicles which utilized electric motors powered by a rechargeable onboard battery, plug-in hybrid electric vehicles which can be simultaneously powered by an electric motor and internal combustion engine, hybrid electric vehicle which utilizes both an electric motor powered by a battery and internal combustion engine, and fuel cell electric vehicle that is driven by electricity generated by fuel cells that utilizes hydrogen and oxygen from the air [17]. The rising demand for electric vehicles is due to its several advantages over conventional vehicles. Studies have shown that electric vehicles are energy efficient in that about $60 \%$ of the electrical energy from the grid is converted to power at the wheels compared to about $20 \%$ of the energy stored in gasoline for powering at the wheel for internal combustion engine vehicles [18]. In addition, an electric vehicle has zero emission of carbon dioxide and other tailpipe pollutants as well as less maintenance, smooth operation and stronger acceleration compared to the internal combustion engine vehicles. A study of life cycle greenhouse gas emission reduction potentials of a battery in electric vehicles by Wu et al. [19] revealed that the total life cycle greenhouse gas reduction potential of the electric vehicle is dependent on an optimized electricity mix, advances in electricity generation technology and the increase in combined heat and power scale. Since there is an increasing awareness and demand for electric vehicles, it becomes necessary to determine the total cost associated with the entire life cycle of the electric vehicle which will help stakeholders and investors in the decision-making process. Moreover, life cycle costing will enable the holistic evaluation of all the costs associated with the whole life of the electric vehicle thereby helping to determine the detail costs incurred in the entire life cycle of the electric vehicles. The evaluation of total life cycle costs could also be employed as a crucial criterion in a comparative analysis between electric vehicles and the internal combustion engine vehicles.

Several review articles have been published on life cycle cost analysis. Islam et al. [20] presented a review on the life cycle cost analysis of the residential building. The authors critically discussed the tools, frameworks, and processes involved in the life cycle cost of different types of buildings and evaluate the variation in the life cycle costs of the various building. Babashamsi et al. [21] reported a review of the life cycle cost analysis of pavement. The review examines the different life cycle cost models that have been employed in the evaluation of pavement design, maintenance and rehabilitation. A recent review of the life cycle cost analysis of recycled solid waste materials in highway pavement was presented by $\mathrm{Li}$ et al. [22]. Based on the review analysis, the net present value was the most practical economic indicator employed in the life cycle cost analysis of the recycled solid waste materials in highway pavement. To the best of the authors' knowledge, there is presently no literature on a systematic review of life cycle cost analysis of electric vehicles. The objective of this study is to systematically review various published articles on life cycle costanalysis of electric vehicles, with a view to determining the research trend over the years. The review will serve as a guide to stakeholders and investors in formulating decision-based criteria on electric vehicles. Moreover, the review will also help to highlight the grey research areas in the life cycle cost analysis of electric vehicles. 

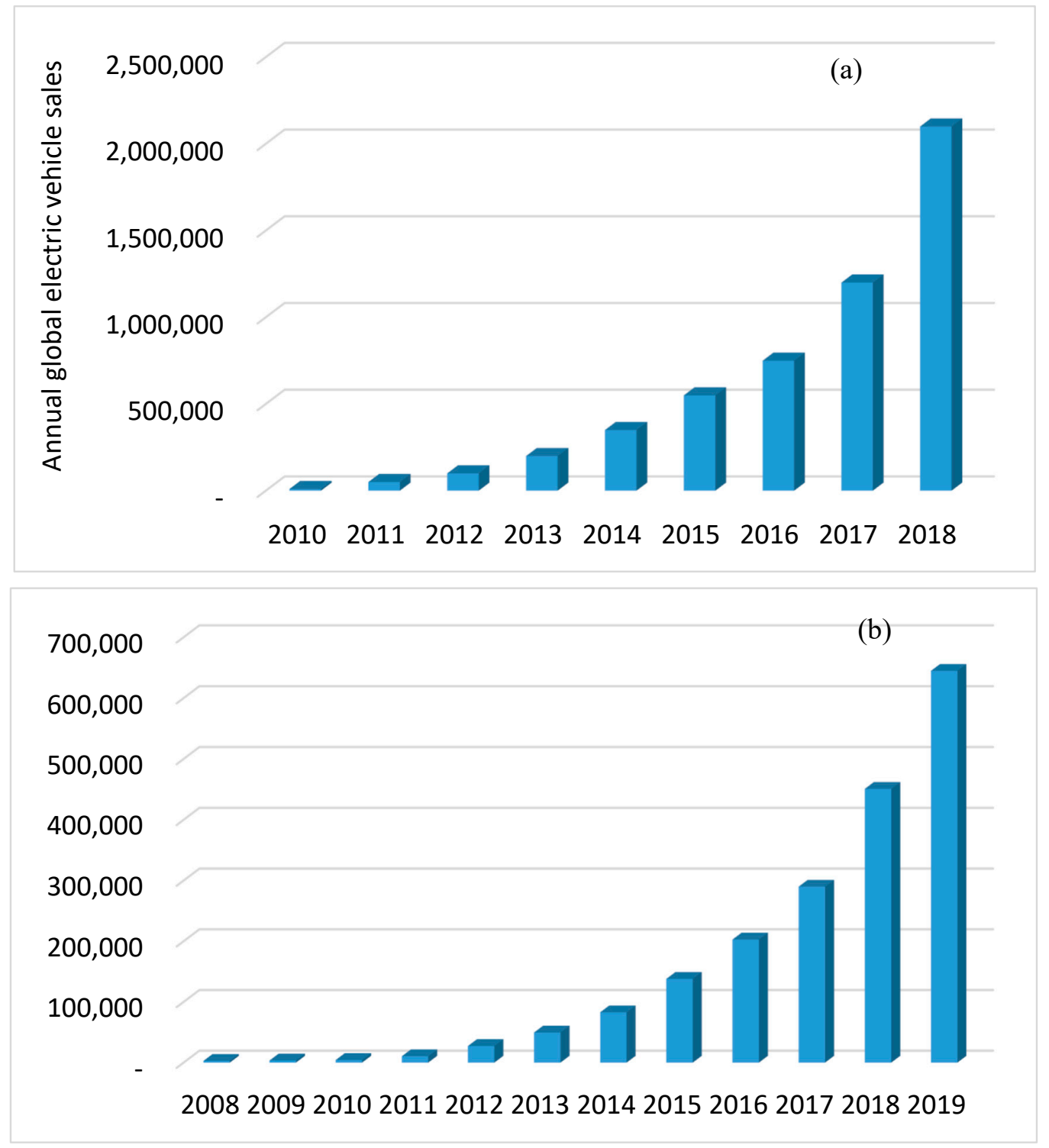

Figure 1. (a) Annual global sales of electric vehicle (b) total number of battery electric vehicles (BEVs) in European Union [14,23].

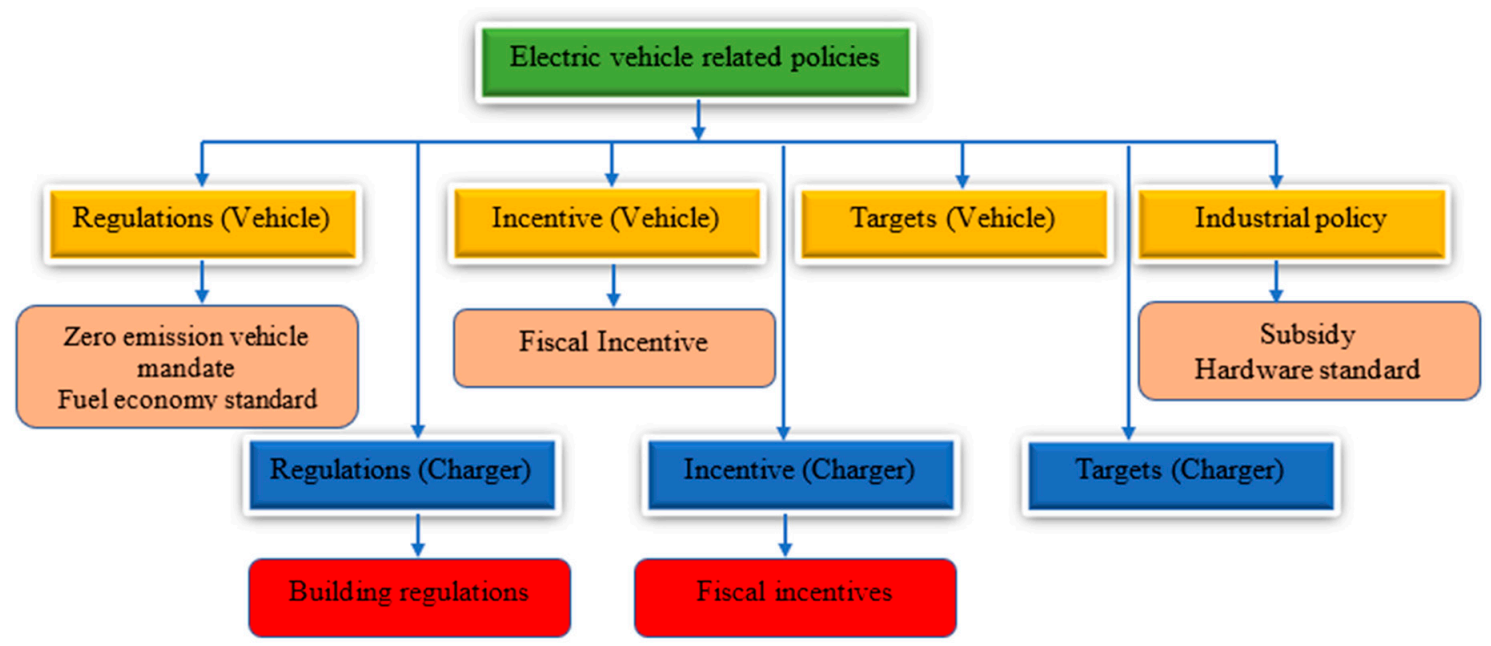

Figure 2. Various policies formulated for electric vehicles. 


\section{Overview of Different Life Cycle Cost Frameworksfor Electric Vehicles}

Based on the framework developed by Diao et al. [24] and illustrated in Figure 3, the life cycle cost analysis of electric vehicles is primarily made of the tangible and the intangible cost. The tangible costs consist of the purchase cost, the retail cost, and the operating cost while the intangible costs could either be the costs due to purchase restrictions or costs of driving restriction. The purchase costs as intangible costs are those costs the manufacturers' suggested retail cost, subsidies and purchase tax. While the operating costs are those costs associated with energy consumption by the electric vehicle, maintenance, use tax, and insurance. Contrary to the work of Diao et al. [24], Kara and Sadjiva [25] developed a framework for the total consumer life cycle cost of electric vehicles that took into consideration the acquisition phase, the operating phase, and disposal phase. The cost associated with the acquisition stage consists of the manufacturers' suggested retail price for the vehicle and level 2 charger, Tax, and third-party insurance. While the cost associated with the electric vehicle operating stage includes the recharging electricity, maintenance, battery replacement, insurance and tire replacement. The cost of the disposal is associated with the scrap value of the electric vehicle, and battery recycling cost. Unlike, Diao et al. [24], Kara and Sadjiva [25] did not include the cost for subsidizing the electric vehicle, intangible cost of purchase restriction and intangible cost of driving restriction. Moreover, Lin et al. [26] formulated a framework on the life cycle cost of electric vehicles. The life cycle cost was made up of three components, namely the initial cost, ownership costs, and cost/income of recycling or scrapping. The initial cost component was further broken down to manufacturers, suggested retail values, purchase tax, registration fees, license fees, and government subsidies. The ownership cost consists of energy cost, inspection and maintenance cost, tax, insurance and fees, and other fees. It can be seen that the life cycle cost framework developed by Diao et al. [24] and Lim et al. [26] has similar contents.

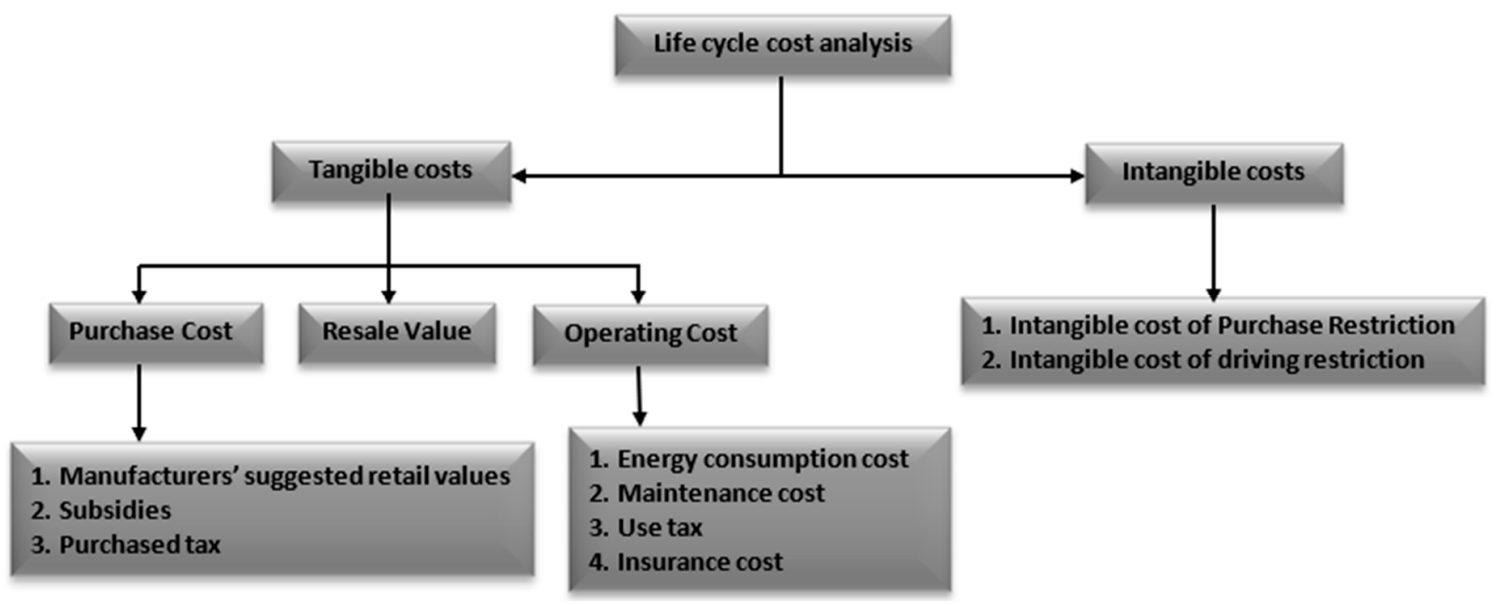

Figure 3. Components of life cycle cost analysis of electric vehicles [24].

\section{Review Methodology}

\subsection{Review Approach}

The guidelines proposed by Pullin and Stewart [27] for systematic literature review were adopted in this study. In accordance with the guidelines, the systematic review is divided into three stages, namely, planning of the review, conducting the review, and reporting and dissemination of the results. The planning stage involves question formulation and developing a review protocol. The steps for conducting the systematic review include searching for data, selection of relevant data, assessing the quality of the data, and data extraction/analysis. The final stage entails reporting and dissemination of the results. Some of the steps stated above were slightly modified to fit the purpose of the present study. The need for the present review arises from the quest to have a holistic view of recent trends in the life cycle cost analysis of electric vehicles in various countries across the world. The study will serve as a 
guide that will aid researchers and other stakeholders to form their opinions based on the trends in the life cycle cost analysis of electric vehicles. Due to the unavailability of specific databases on life cycle cost analysis, the protocol for the systematic review of the life cycle cost assessment of electric vehicles was not registered. The availability of such databases could have helped in minimizing the bias of related systematic reviews as well as provide the opportunity for the identification of areas of the systematic review that requires further assessment.

\subsection{Review Planning}

In this stage, the specific questions to be addressed in the course of the systematic review are presented. The formulation of the specific questions would help in obtaining the necessary search terms and aid in identifying relevant criteria [27]. Besides, the detailed protocol for the systematic review is also presented. The specific questions to be addressed in the systematic review are as presented below: What is the trend in the scientific literature on life cycle cost analysis of electric vehicles?

How does the life cycle cost of EVs vary with the model?

\subsection{Conducting the Review}

Relevance databases such as Scopus and Web of Science were employed for searching the review articles related to life cycle cost assessment of electric vehicles. Prior to the article search in the databases, the inclusion criteria in the search were determined. In this study, the inclusion criteria consists of published articles on life cycle cost assessment of electric vehicles between 2001 and November 2019 published in English. Moreover, only published articles indexed in Scopus and Web of Science were considered. Conference papers, books, book chapters, case studies, reports, editorials and review articles were excluded from the search [28]. The search strings consist of the combination of the title which includes "life cycle cost of electric vehicles"; "life cycle cost analysis of electric vehicles"; "life cycle cost assessment of electric vehicles"; and "cost analysis of electric vehicles". After each search, a double check by the authors was ensured to remove any irrelevant and duplicated articles from the search lists. After the search, the dataset for the relevant articles was extracted and sorted using Microsoft Excel spreadsheets. The retrieved published articles were sorted based on the country in which the life cycle cost assessment was conducted, and the life cycle cost assessment methodology.

\subsection{Bibliometric Analysis}

Bibliometric analysis was conducted on the retrieved literature from Scopus and Web of Science databases. The bibliometric analysis is an established technique that has been employed to evaluate the performance of research in the Universities. The impact of research in various fields, as well as the respective researchers, have been studied using the bibliometric method. Based on the bibliometric method, citation analysis of each of the journals that publish the articles related to the life cycle cost analysis of electric vehicles was presented in this study. The use of bibliometric analysis for reviewed literature on green supply chain management has been reported by Fahimnia et al. [29]. The authors reported that the use of bibliometric analysis provided a graphical illustration of the publication's evolution in the field of green supply chain management over time and helps to identified potential areas of research for further study. Moreover, the bibliometric technique has been applied to analyze the literature trend on production planning and control [30], business economics [31], and outdoor air pollution and respiratory health [32].

\section{Results and Discussion}

The search protocol for the systematic review is depicted in Figure 4. The initial search of the Scopus and Web of Science databases using the search string "life cycle cost analysis of electric vehicles" yielded 482 documents. The 482 documents are mainly articles (260), conference papers (182), reviews (15) conference reviews (15), book chapters (8) and books (2) published from 1981 to 2020, in several subject areas such as Engineering, Material Science, Mathematics and so on. A further search was 
initiated limiting the inclusion criteria to only articles published from 2001 to 2020 with the subject area in Energy. Moreover, keywords such as electric vehicles, life cycle cost, operating cost, cost-benefit analysis, and total cost of ownership were used. After the inclusion criteria, the number of documents was reduced to 143. A quick screening of the documents based on the titles was performed on the 143 documents and subsequently reduced to 73 . The 73 articles were further reviewed based on the abstracts to obtain the final 42 articles included in the study.

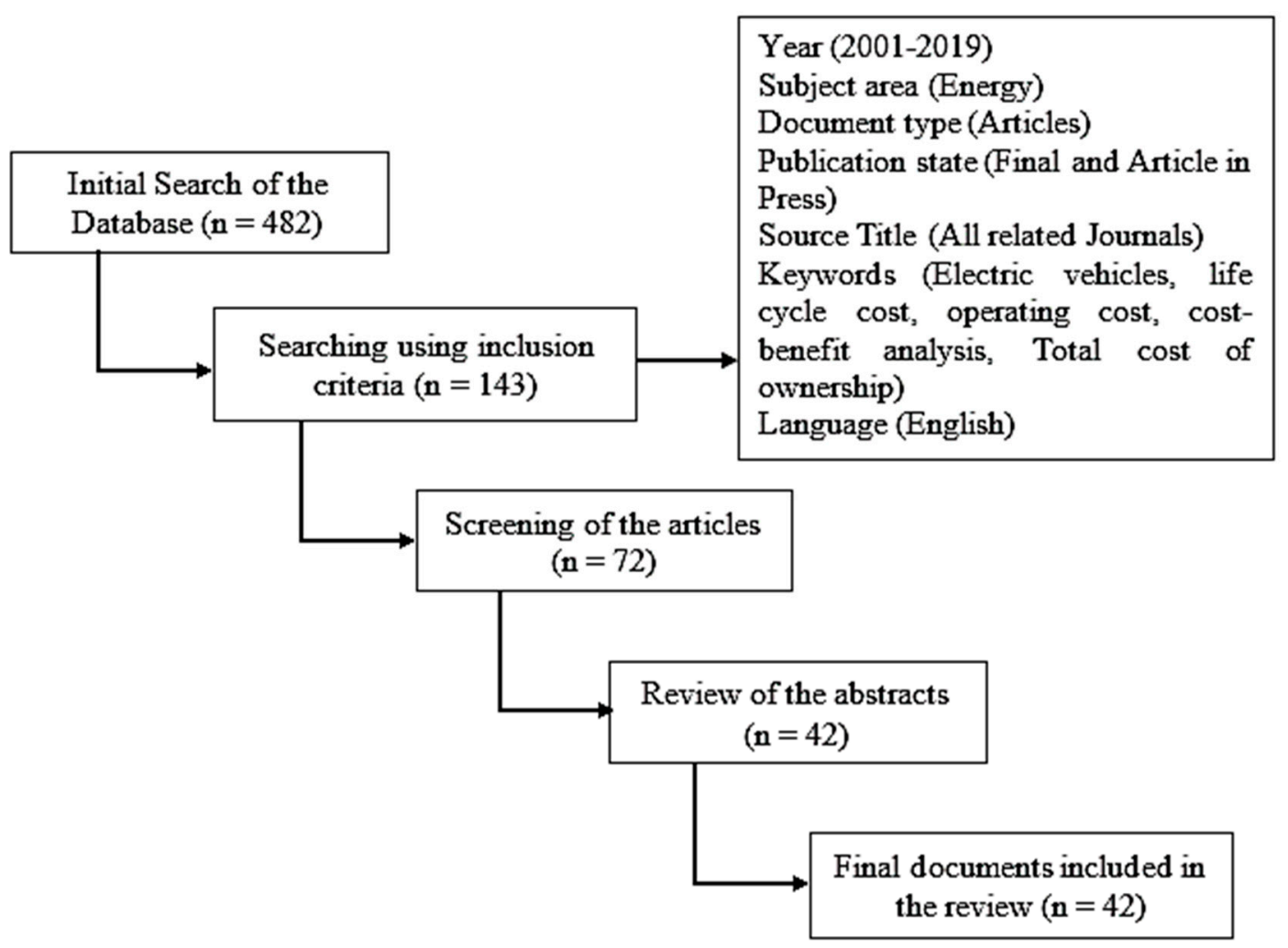

Figure 4. The search protocols for the systematic review.

\subsection{Time Trend of Publications}

The number of publications by year on the life cycle of EVs is depicted in Figure 5. Prior to 2010, there was little research attention on the life cycle cost analysis of EVs. This could be attributed to less awareness regarding the role of EVs in decarbonizing the transportation sectors. A sharp increase was recorded in 2011 which subsequently declined in 2012. Since 2013, the number of publications on life cycle cost has been on the increase which implies an increase in research interest on the life cycle cost analysis of EVs. The trend also revealed that life cycle cost analysis is increasingly being appreciated in the EV research as a vital tool in decision making and management of the assets related to EVs [33]. The relatively low publications recorded in 2019 could be attributed to the delay in most of the articles submitted in Scopus and Web of Science indexed Journals. Life cycle cost analysis as a tool that can be employed to estimate the total costs of the EV at the early stage is useful in identification and selection of models for the cost analysis that were employed to evaluate their competitiveness with the conventional internal combustion engine vehicles. 


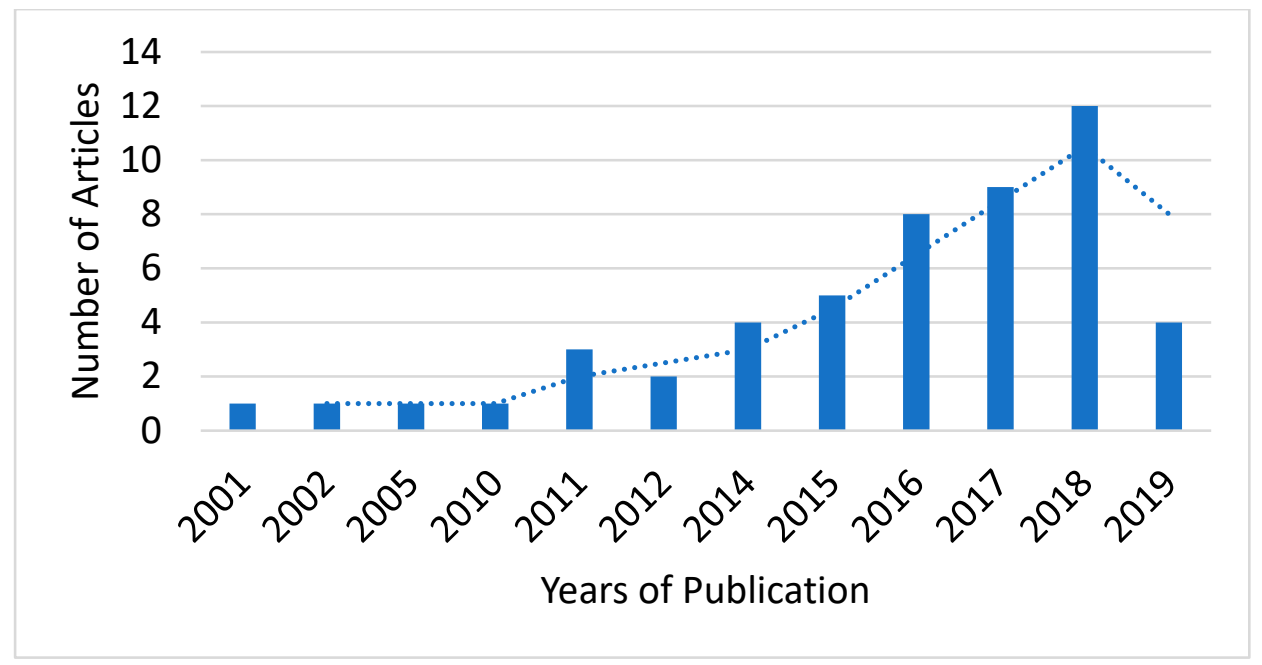

Figure 5. Time trend of publications on LCC (life cycle cost) of EVs (electric vehicles).

\subsection{Geographical Distribution of the Published Articles on LCC of EVs}

Figure 6 depicts the geographical distribution of publications on life cycle cost analysis of EVs based on the authors' affiliation. It can be seen that the research on life cycle cost analysis of EVs is dominated by the United States and China. Australia, Germany, South Korea, and Switzerland were fairly represented. Studies have shown that the United States and China have the largest EV markets. This could be a result of incorporating EVs as a means of decarbonizing the transportation sector as both the US and China have the highest $\mathrm{CO}_{2}$ emission in the world from the transportation sector. Hence, several policies have been initiated by both the Chinese and US government to support the production and utilization of EVs for transportation. In the US, several policies and legislations have been enacted to promote the EV market. Moreover, a series of programs have been undertaken to promote research and development in EVs and also to facilitate investments in EVs and EV infrastructure. One of such policies is the offering of financial incentives in forms of tax credits and tax exemptions as well as different forms of subsidies. In China, between 2014 and 2017, purchase tax was excerpted for purchasing EVs in order to encourage ownership. In addition to the purchase tax exemption, there were several subsidies which the regime put in place by the government to encourage ownership of EVs in China [18].

\subsection{Journal Analysis}

The number of journals in which the articles on life cycle cost analysis of EVs were published is represented in Figure 7 and Table 1. The publications on life cycle assessment of EVs are mostly published in the Journal of Applied Energy with H-index of 168. The H-index of the Applied Energy Journal is a measure of productivity and the citation impact. This implies that the Applied Energy Journal is a high impact journal indexed in both Scopus and Web of Science. Moreover, journals such as Energy, World Electric Vehicle Journal, Energies, Journal of Cleaner Production, Journal of Power Source, also have a fair share of publications on life cycle cost analysis on EVs. The high $\mathrm{H}$-index of these journals is an indication of their citation impacts. Interestingly, most of the articles published in these journals have received a reasonable number of citations, as shown in Table 1. 

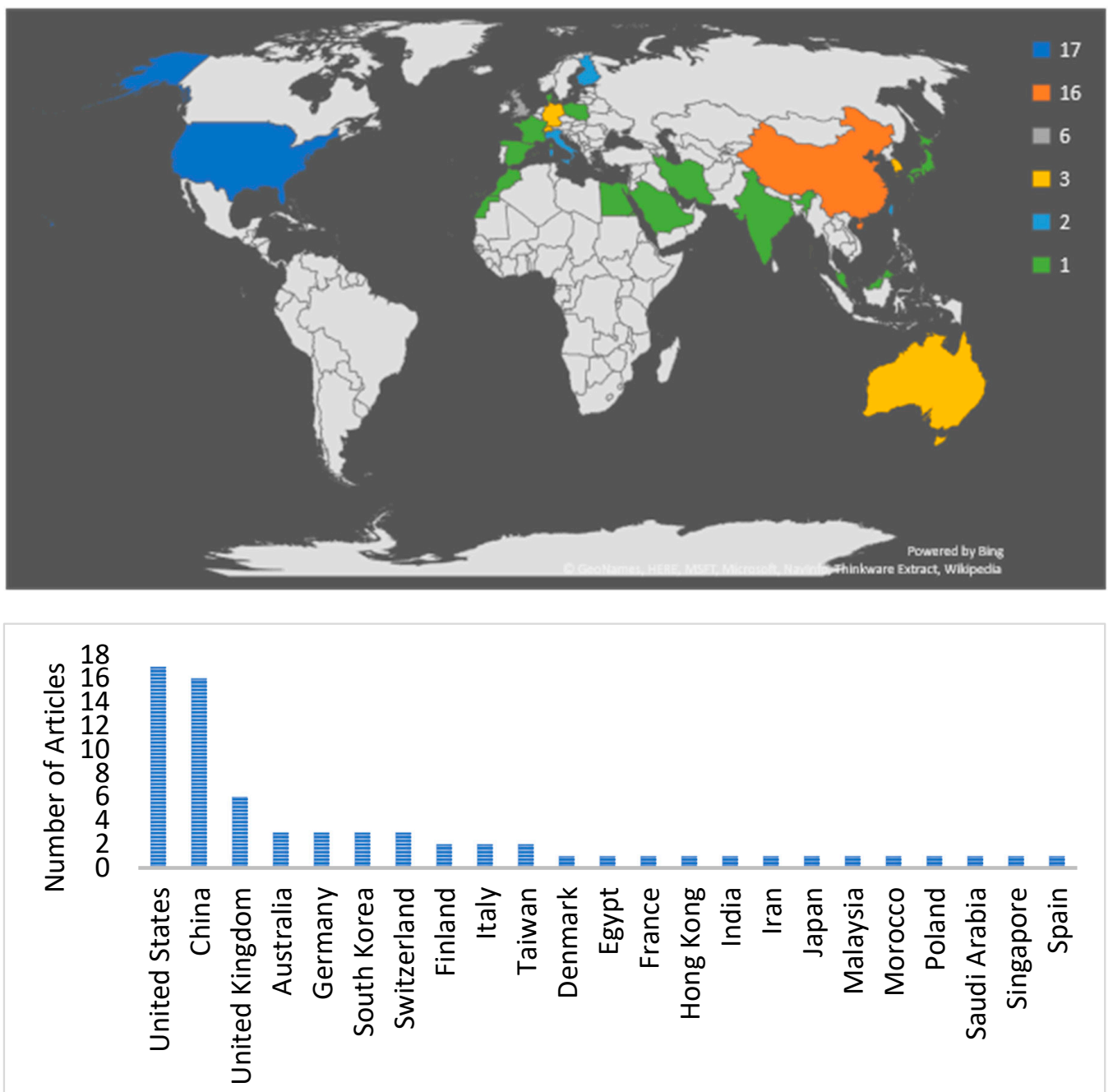

\section{Countries}

Figure 6. Geographical distribution of the published articles on LCC of EVs.

Table 1. Journal analysis of selected studies on LCC of EVs.

\begin{tabular}{llccc}
\hline \multicolumn{1}{c}{ Article } & \multicolumn{1}{c}{ Journal } & Citation & H Index (SJR) & Reference \\
\hline $\begin{array}{l}\text { Influence of driving patterns on life cycle cost } \\
\text { and emissions of hybrid and plug-in electric } \\
\text { vehicle powertrains }\end{array}$ & Energy Policy & 166 & 178 & [34] \\
\hline $\begin{array}{l}\text { Cost analysis of plug-in hybrid electric vehicles } \\
\text { including maintenance and repair costs and } \\
\text { resale values }\end{array}$ & $\begin{array}{l}\text { World Electric Vehicle } \\
\text { Journal }\end{array}$ & 93 & 13 & [35] \\
\hline $\begin{array}{l}\text { Electric vehicles in Portugal: An integrated } \\
\text { energy, greenhouse gas and cost life } \\
\text { cycle analysis }\end{array}$ & IEEE & 22 & 250 & [36] \\
\hline $\begin{array}{l}\text { Life cycle private costs of hybrid electric } \\
\text { vehicles in the current Chinese market }\end{array}$ & Energy Policy & 52 & 178 & [26] \\
\hline $\begin{array}{l}\text { Life cycle private cost-based competitiveness } \\
\text { analysis of electric vehicles in China considering } \\
\text { the intangible cost of traffic policies }\end{array}$ & $\begin{array}{l}\text { Applied Energy } \\
\begin{array}{l}\text { Life cycle cost analysis of different vehicle } \\
\text { technologies in Singapore }\end{array}\end{array} \quad \begin{array}{l}\text { World Electric Vehicle } \\
\text { Journal }\end{array}$ & 14 & 162 & [24] \\
\hline $\begin{array}{l}\text { Energy consumption and cost-benefit analysis } \\
\text { of hybrid and electric city buses }\end{array}$ & $\begin{array}{l}\text { Transportation Research Part } \\
\text { C: Emerging Technologies }\end{array}$ & 197 & 100 & [37] \\
\hline
\end{tabular}


Table 1. Cont.

\begin{tabular}{|c|c|c|c|c|}
\hline Article & Journal & Citation & H Index (SJR) & Reference \\
\hline $\begin{array}{l}\text { Does a battery-electric truck make a } \\
\text { difference?-Life cycle emissions, costs, and } \\
\text { externality analysis of alternative fuel-powered } \\
\text { Class } 8 \text { heavy-duty trucks in the United States }\end{array}$ & $\begin{array}{l}\text { Journal of Cleaner } \\
\text { Production }\end{array}$ & 54 & 150 & [39] \\
\hline $\begin{array}{l}\text { The economic competitiveness and emissions of } \\
\text { battery electric vehicles in China }\end{array}$ & Applied Energy & 46 & 162 & [40] \\
\hline $\begin{array}{l}\text { Electric vehicle cost, emissions, and water } \\
\text { footprint in the United States: development of a } \\
\text { regional optimization model }\end{array}$ & Energy Policy & 68 & 178 & [41] \\
\hline $\begin{array}{l}\text { Electric vehicles for greenhouse gas reduction in } \\
\text { China: A cost-effectiveness analysis }\end{array}$ & $\begin{array}{l}\text { Transportation Research Part } \\
\text { D: Emerging Technologies }\end{array}$ & 34 & 100 & [42] \\
\hline $\begin{array}{l}\text { Life cycle environmental and economic impact } \\
\text { assessment of alternative transport fuels and } \\
\text { power-train technologies }\end{array}$ & Energy & 28 & 158 & [10] \\
\hline $\begin{array}{l}\text { A cost-benefit analysis of electric loaders to } \\
\text { reduce diesel emissions in underground hard } \\
\text { rock mines }\end{array}$ & IEEE & 23 & 250 & [43] \\
\hline $\begin{array}{l}\text { The development pattern design of Chinese } \\
\text { electric vehicles based on the analysis of the } \\
\text { critical price of the life cycle cost }\end{array}$ & Energy Policy & 6 & 178 & [44] \\
\hline $\begin{array}{l}\text { A cost-benefit analysis of V2G electric vehicles } \\
\text { supporting peak shaving in Shanghai }\end{array}$ & $\begin{array}{l}\text { Electric Power System } \\
\text { Research }\end{array}$ & & 104 & [45] \\
\hline $\begin{array}{l}\text { Life Cycle Cost Analysis of Electrical Vehicles in } \\
\text { Australia }\end{array}$ & Procedia CIRP & 12 & 41 & [25] \\
\hline $\begin{array}{l}\text { An optimal electric vehicle investment model } \\
\text { for consumers using total cost of ownership: } \\
\text { A real option approach }\end{array}$ & Applied Energy & & 162 & [46] \\
\hline $\begin{array}{l}\text { Total cost of ownership and externalities of } \\
\text { conventional, hybrid and electric vehicles }\end{array}$ & $\begin{array}{l}\text { Transportation Research } \\
\text { Procedia }\end{array}$ & 19 & 17 & [47] \\
\hline $\begin{array}{l}\text { Total cost of ownership and market share for } \\
\text { hybrid and electric vehicles in the UK, US } \\
\text { and Japan }\end{array}$ & Applied Energy & 90 & 162 & [48] \\
\hline
\end{tabular}

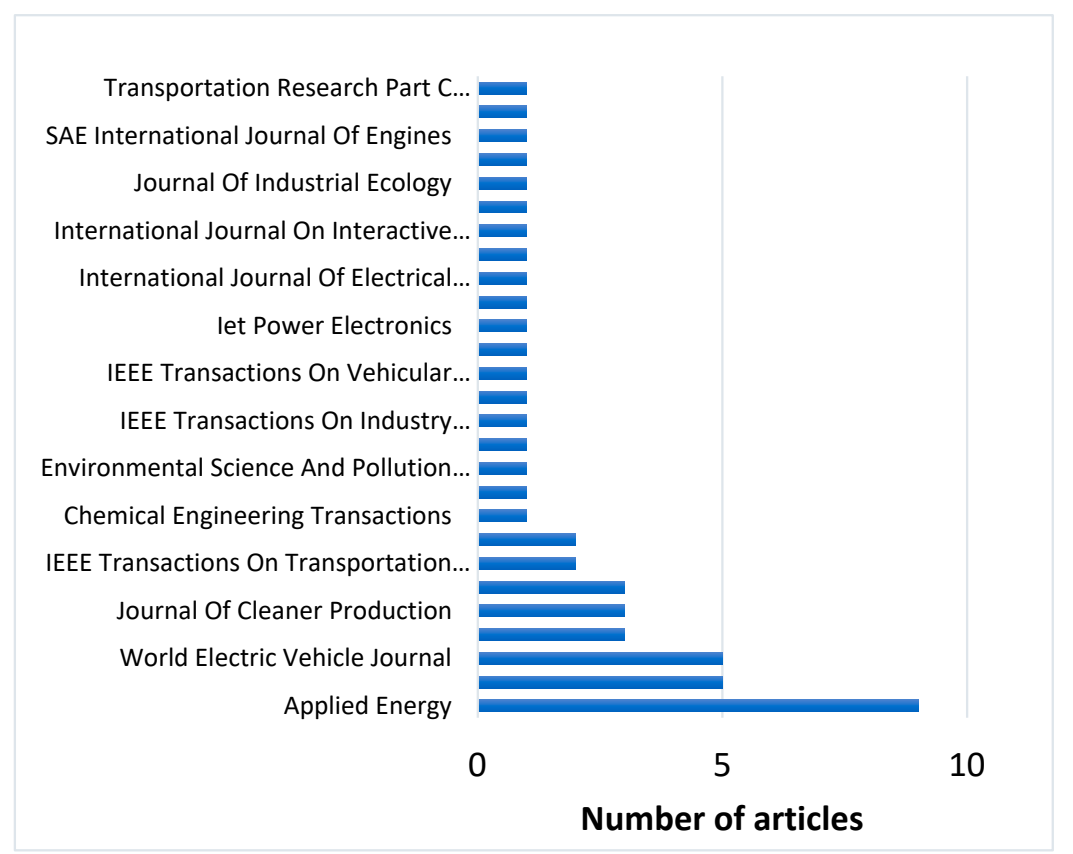

Figure 7. Publication frequencies of LCC of EVs in different journals. 


\subsection{Comparison of the LCC of the Different EV Model}

The LCC of the different model of EVs obtained from literature are depicted in Figure 8. The LCC varies with the type of EVs. The variation in the LCC values is dependent on factors such as the type of the model used, the type of EVs, existing government policies and the prevailing economic factors in the countries where the study was performed. Diao et al. [24] reported the competitiveness of EVs in China based on the LCC analysis. The authors revealed that the competitiveness of EVs in China is dependent on factors such as government promotions and policies and the impact of non-economic incentive policies. Incentives such as exemption of the EVs from purchase restrictions and driving restrictions were operational in China under the study period. The LCC of the BALK EV 200 BEV and the BYD e6 BEV reported by Diao et al. [24] was modeled based on the intangible cost of purchase and driving restrictions in China. A higher LCC of US\$2.63 million was obtained for the BYD e6 BEV brand compared to US $\$ 1.80$ million obtained for the BALK EV 200 BEV brand. The authors concluded that the tangible costs of the EVs were not economically competitive with conventional vehicles. In a similar study, Hao et al. [42] investigated the LCC of three models of EVs based on the size of the batteries. The EV with the largest battery size was coded as EV 300 while the EV with the lowest battery was coded as EV 100. The results showed that the LCC varies depending on the size of the batteries with EV 300 having the highest LCC and EV100 having the lowest EV. The authors concluded that the EVs were not competitive enough in terms of cost in China under the study period. The LCC of the two models of EVs was lower compared to hydrogen EVs. Wong et al. [37] conducted an LCC analysis of different EV models in Singapore. As shown in Figure 9, the result revealed that the LCC is dependent on the types of EVs. The Mitsubishi brand of the EV was found to have the highest LCC cost compared to the other types of EVs. A low LCC was obtained for prototype EVs as reported by Hao et al. [42], Propfe et al. [35] and Kara et al. [25] which are competitive with the hybrid EVs reported by Wong et al. [37].

The LCC on the EVs in China reported by the various authors can be tied to the effect of the various government policies. Zhang et al. [49] identified several policies on electric vehicles in China that have promoted the increase in its demand. One of such policies is the national finance policy jointly issued by the Ministry of Finance, the Ministry of Science and Technology, and Ministry of Industry and Information Technology in 2013. Based on the policy, it was believed that the cost of EVs will drastically reduce through the commercialization process. In addition, the national infrastructure promotion policy for EVs was also operational to make charging poles more assessable to various EV consumers by promoting the construction planning, interface standardization and the charging pricing policies [49]. Based on the LCC of EVs conducted in Singapore, Wong et al. [37] established that the LCC of the EVs was yet to be competitive with the conventional internal combustion engine cars. The LCC of the EVs was divided into Societal and Consumer categories. The societal LCC, which is the totality of the cost of environmental externality and the economic impact, is lower than the consumer LCC which measures the economic impacts from the EV's perspective [50]. The high cost of the EVs was attributed to the cost of the batteries which could be attributed to low patronage of EVs in Singapore, as EVs currently made up $0.2 \%$ of the total car population as of 2019. Hence, there is a need to promote policy to encourage participation in purchasing EVs and in investment in charging infrastructure to make it accessible. Comparing the LCC of EVs and internal combustion engine vehicles, Figure 10 shows that the LCC of the EVs reported by AECOM [51], Bakker [52], Crist [53], and Kara et al. [25] were higher than that of the corresponding internal combustion engine vehicles. Although, the LCC for EVs reported by EPRI [54] was lower than the internal combustion engine vehicle which was attributed to the model assumptions that supported EVs. Due to variation in the assumptions, methodologies and peculiarities of each country in terms of existing policies and legislations, it might be difficult to make a holistic comparison between the LCC of EVs and internal combustions engine vehicles. However, the speedy implementation of necessary policies on EVs could bring about a significant reduction in the cost of batteries, which, in turn, yield a gradual reduction in 
the LCC of BEVs. The details of policies and legislations on EVs by different countries is summarized in Table 2 and explained in Section 4.

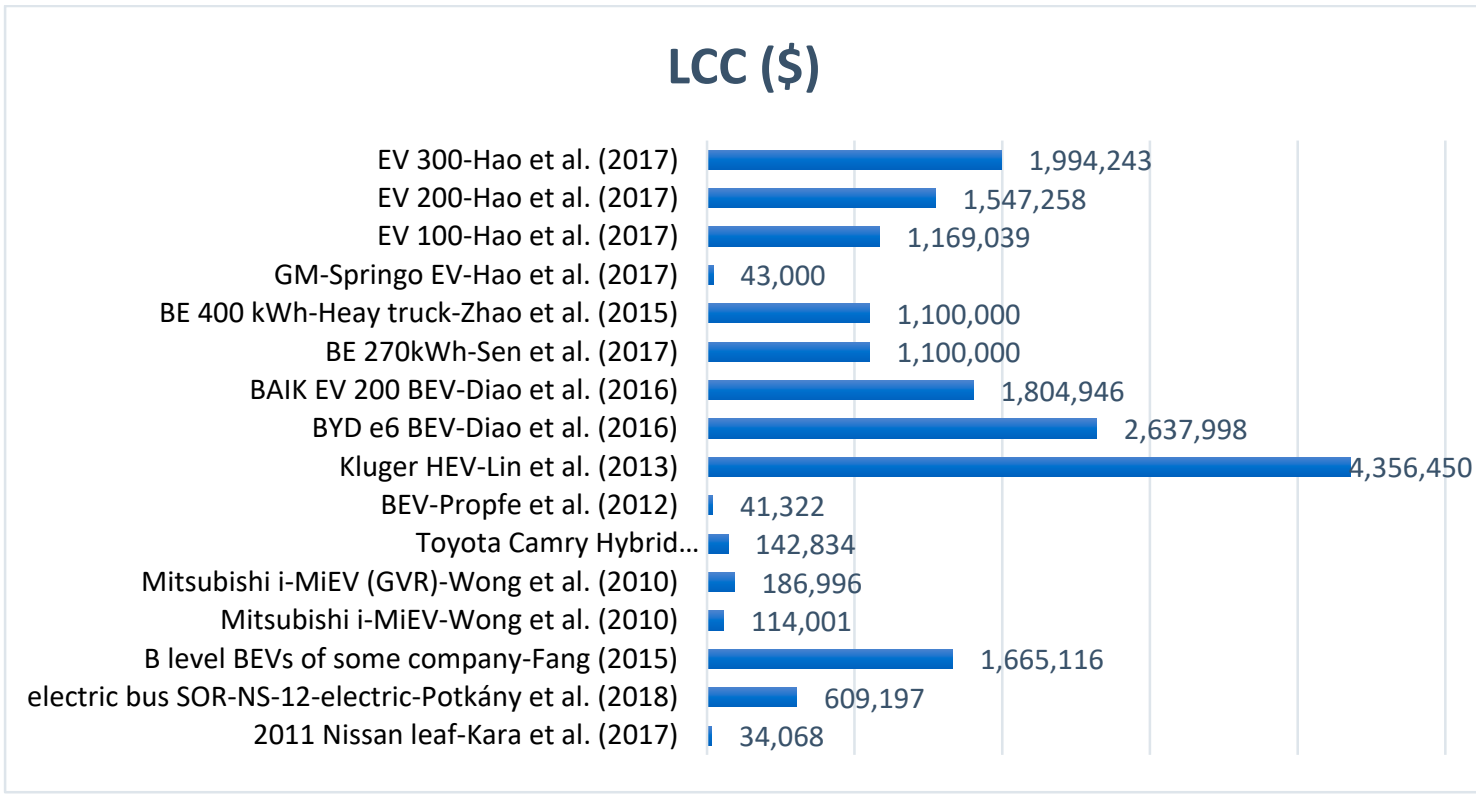

Figure 8. Comparison of the LCC of different EV models obtained from literature. (Note: LCC obtained from some of the studies were converted from the local currency to US dollars based on the conversion rate of the year the study was published).

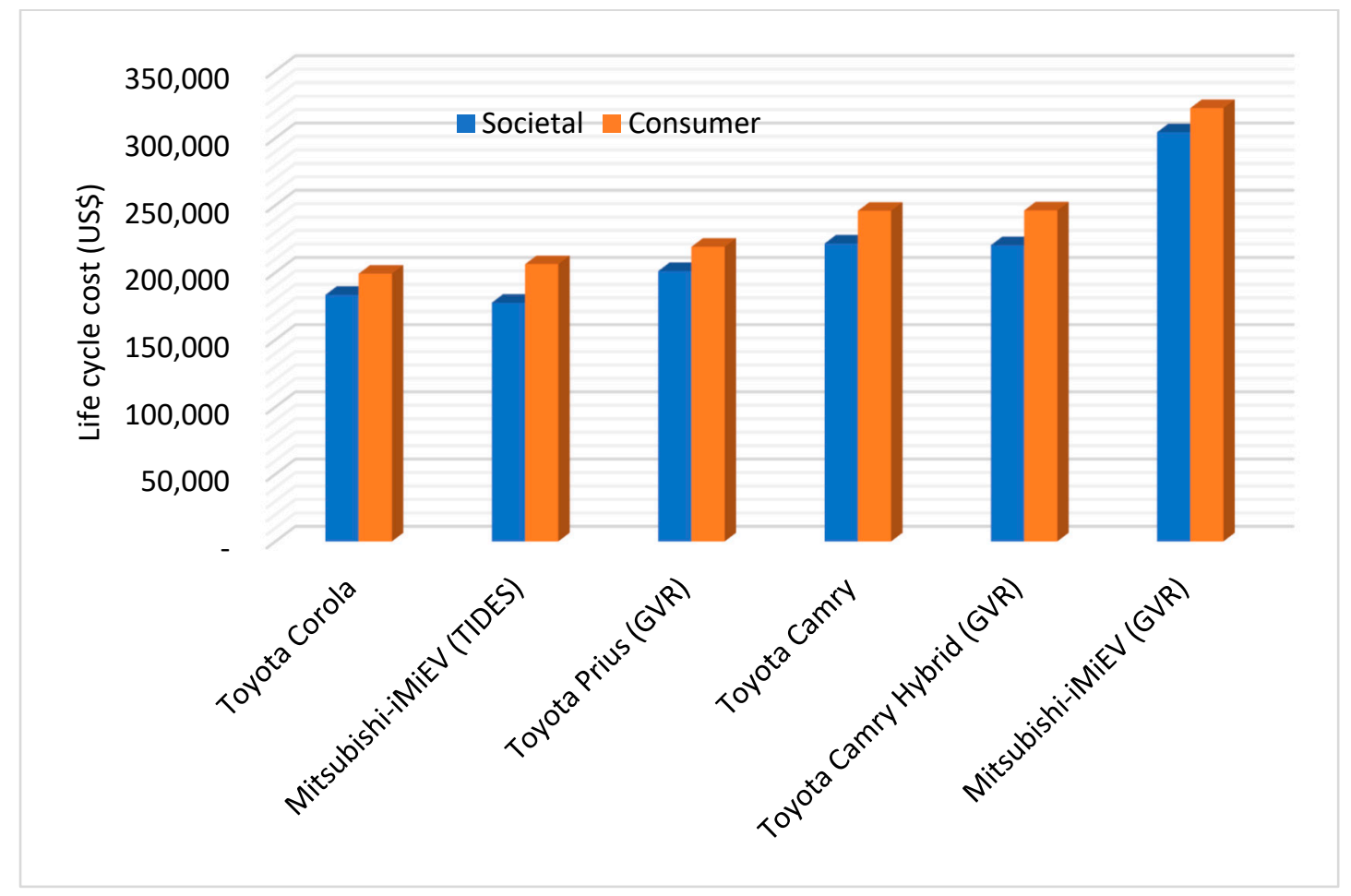

Figure 9. The comparison of life cycle costs of different EVs with conventional vehicles (adapted from Wong et al. [37]) (Note: LCC obtained from Wong et al. [37] was converted from the local currency to US dollars based on the conversion rate of the year the study was published). 


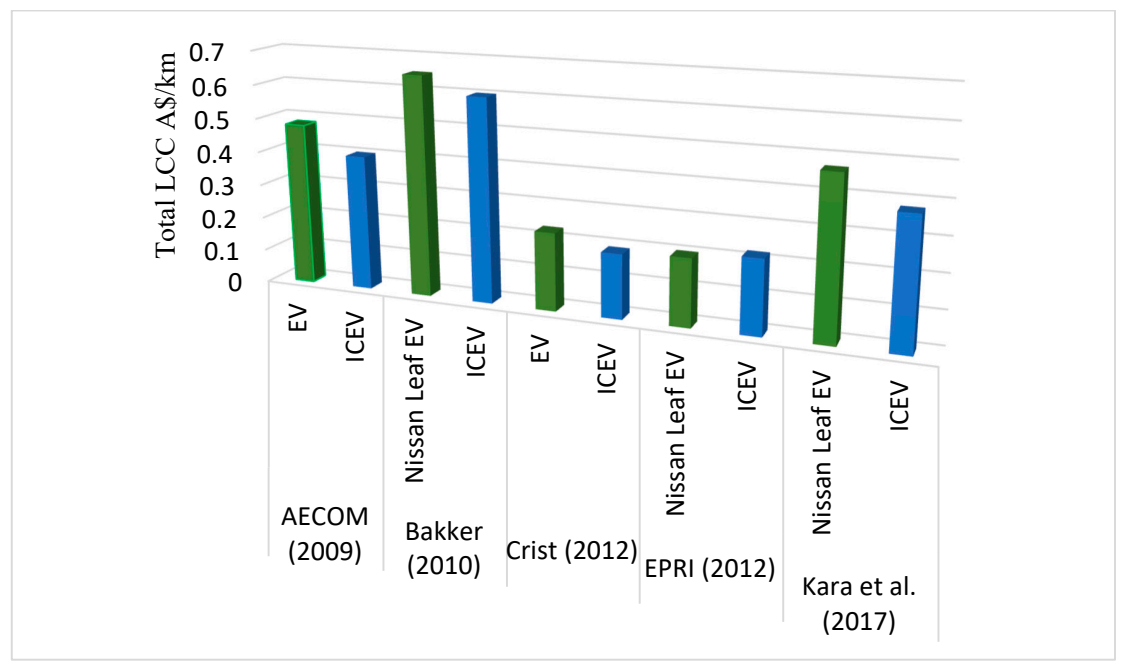

Figure 10. The comparison of life cycle cost analysis of EVs and internal combustion engine vehicles (ICEV) based on the studies performed in Australia (adapted from [25]).

\subsection{Bibliometric Analysis Using VOSviewer}

The bibliometric analysis based on the thematic cluster map of the keywords extracted from the contents of the published articles on life cycle cost analysis of EVs is represented by the VOSviewer visualization map in Figure 11 The visualization map was created using the title and the abstracts of the 42 published articles obtained from Scopus and Web of Science databases which were subsequently analyzed as reported by Bascur et al. [55]. The VOSviewer map visualization helps to identify different key terms that were covered in the 42 published articles analyzed in this study. The most related terms in the selected published articles were analyzed using an algorithm and presented in clusters of circles. The size of the circle in each cluster depicts the numbers of articles captured by the terms. The relationship between each term in the cluster is measured by the distance between the terms. The shorter the distance, the more the terms are related. In the cluster depicted with orange color, terms such as cost analysis, life cycle costs, cost-benefit analysis, electric vehicles, charging batteries, cost-effectiveness and cost analysis are interrelated as indicated by the short distance between them. These terms are commonly found in articles on life cycle cost analysis of EVs. However, terms such as cycle life lithium, lead-acid batteries, energy consumption, and charging station are farther from the orange cluster which implies that the terms are rarely used for the life cycle cost analysis of EVs.

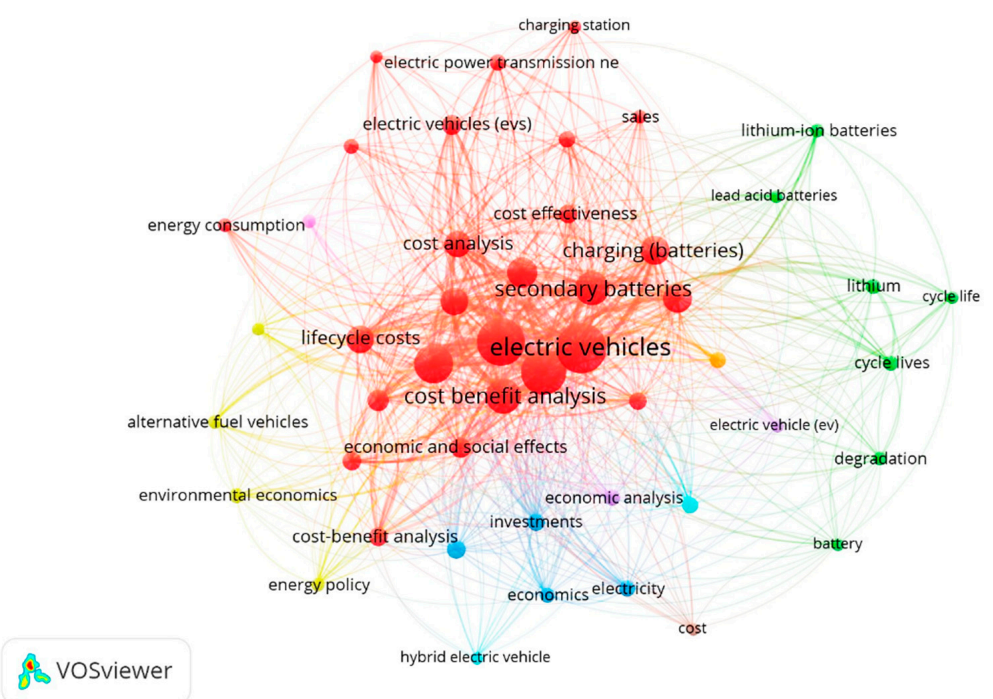

Figure 11. VOSviewer bibliometrics analysis of the published articles on LCC of EVs. 


\section{Implications of the Study in Terms of Existing Policies and Legislations}

Research interest on EVs has been on the increase since the early 1990s, which was propelled by the quest to finding a lasting solution to the rising greenhouse emissions from the transportation sector. According to [56], a series of investments has been made on research and development of EVs to make it competitive with the conventional internal combustion engine vehicles. Countries such as China, the United States, Japan, Germany and the United Kingdom have been spearheading developmental projects on EVs. The US has mapped out plans to reach a target of 14 million EVs in 2020 and 240 million EVs in 2010. Moreover, countries such as Japan, Germany, the UK and China have also set an ambitious target of attaining the target of 13.5 million, 1 million, 12 million and 20 million EVs, respectively. Based on the current research trend on LCC analysis on EVs in different countries, EVs are yet to be cost-effective and competitive with the existing conventional internal combustion engines primarily due to the high cost associated with the manufacturing of the batteries. Although there were variation in terms of assumptions, methodologies employed for the LCC, and policies and legislations regarding EVs, efforts are being made to ensure that the cost of ownership of EVs is competitive with conventional vehicles. Recently, General Electrics and LG announced their intention to spend \$2.3 billion on ventures to produce EV batteries. The management of the companies stated that the take-off of the production in mid-2020 will help to scale up production and drastically facilitate the profitability and affordability of EVs [57]. Additionally, due to the non-affordability of the EVs, a series of policies and legislation have been enacted in several countries, most especially countries like the US, Canada, Spain, the Netherlands, Italy, Turkey, Switzerland, Denmark, France, Germany and so. Table 2 shows a summary of the policies and legislatures of selected countries. Nevertheless, more commitments are still needed to strengthen the existing policies and legislations on EVs' affordability.

Table 2. Summary of policies and legislations by different countries [58].

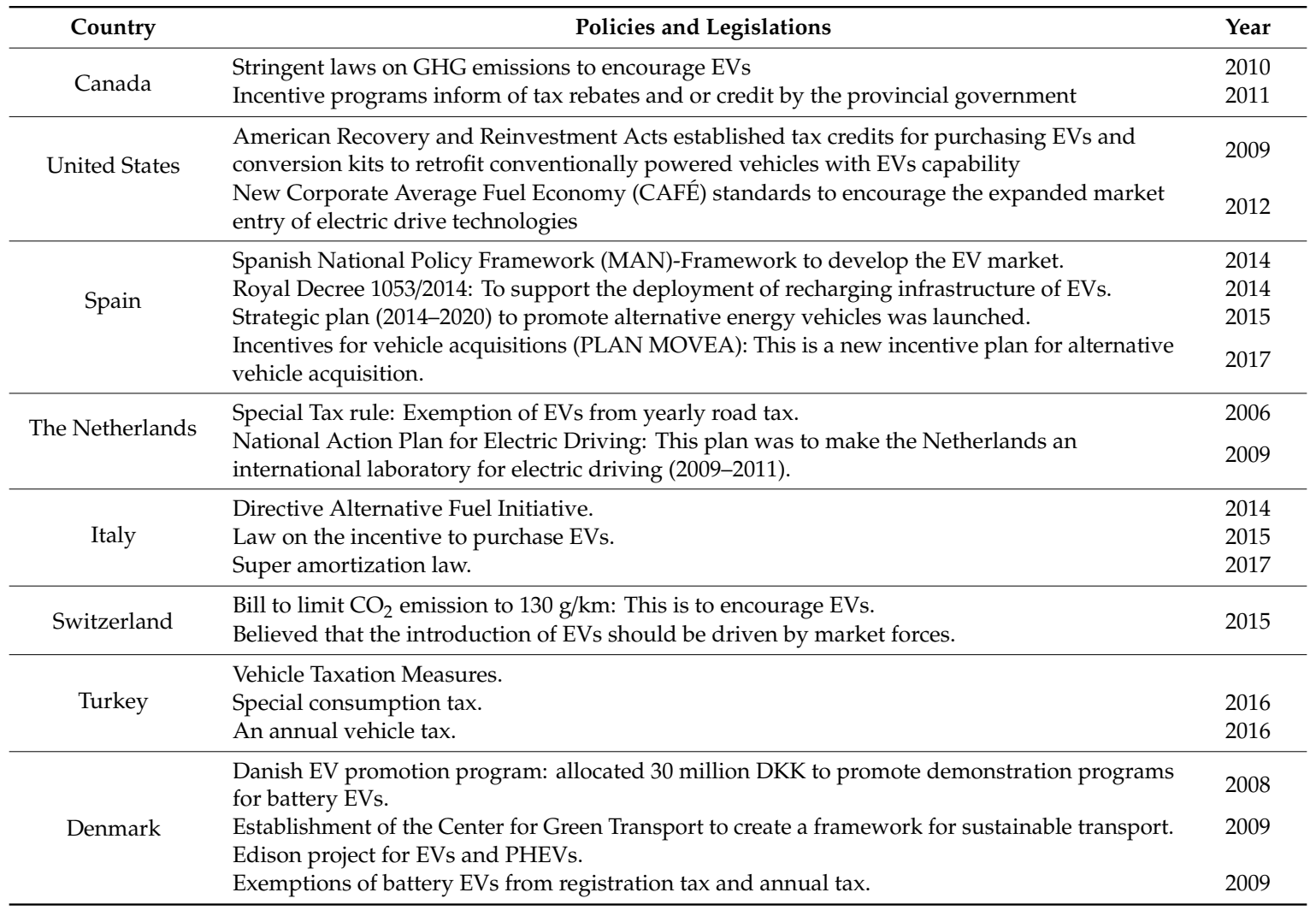


Table 2. Cont.

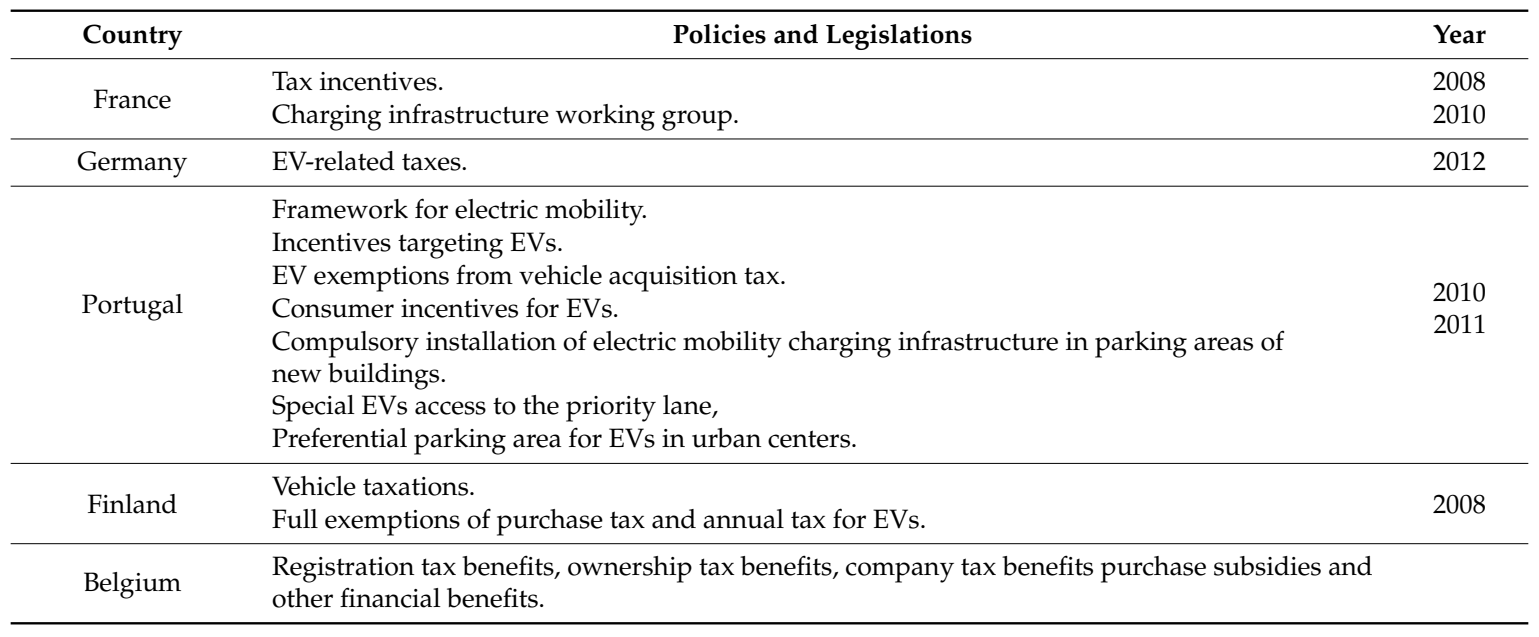

\section{Conclusions and Future Outlook}

This study presents the systematic analysis of published articles on the LCC of EVs. The published literature was sourced from Scopus and Web of Science databases, analyzed and sorted based on set criteria such as the year of publication, the journals, the geographical distributions, and the LCC analysis of the different models of the EV. The time trends of the publications on the LCC of EVs show that the research area is evolving with an annual increase in a number of publications. The geographical distributions of the publications are indications that research on the LCC analysis of EVs is gaining global acceptance, as a result, growing interesting in finding means of making EVs affordable to be owned. The variability in the LCC of the EVs with the models is dependent on the different policies and legislation put in place by the government of different countries. Based on this review, it can be inferred that EVs are presently not cost-competitive with internal combustion engine vehicles. Although, there were some degrees of inconsistency in the assumptions made for the LCC and the methodologies used, research effort should be focused on a basic standard that could be employed for estimating the LCC across different scenarios. This study revealed that cost of ownership of a compact passenger EV was higher than an equivalent internal combustion engine vehicle. However, with a series of efforts and commitments in place to improve the technology most especially batteries improvement, the EVs have been forecasted to be cost-competitive and affordable in the future.

Author Contributions: Conceptualization, B.V.A. and S.I.M.; methodology, B.V.A.; software, B.V.A.; validation, B.V.A., and S.I.M.; resources, S.I.M.; data curation, B.V.A.; writing-B.V.A.; writing-review and editing, B.V.A. and S.I.M.; visualization, B.V.A.; funding acquisition, S.I.M. All authors have read and agree to the published version of the manuscript.

Funding: This research was supported by Universiti Tenaga Nasional with grant number [J510050879].

Acknowledgments: The authors acknowledge the financial support of Universiti Tenaga Nasional.

Conflicts of Interest: The authors declare no conflict of interest.

\section{References}

1. Hofer, C.; Jäger, G.; Füllsack, M. Large scale simulation of $\mathrm{CO}_{2}$ emissions caused by urban car traffic: An agentbased network approach. J. Clean. Prod. 2018, 183,1-10. [CrossRef]

2. Keller, V.; Lyseng, B.; Wade, C.; Scholtysik, S.; Fowler, M.; Donald, J.; Palmer-Wilson, K.; Robertson, B.; Wild, P.; Rowe, A. Electricity system and emission impact of direct and indirect electrification of heavy-duty transportation. Energy 2019, 172, 740-751. [CrossRef]

3. Du, H.; Chen, Z.; Peng, B.; Southworth, F.; Ma, S.; Wang, Y. What drives $\mathrm{CO}_{2}$ emissions from the transport sector? A linkage analysis. Energy 2019, 175, 195-204. [CrossRef] 
4. Kalghatgi, G. Is it really the end of internal combustion engines and petroleum in transport? Appl. Energy 2018, 225, 965-974. [CrossRef]

5. Wanitschke, A.; Hoffmann, S. Are battery electric vehicles the future? An uncertainty comparison with hydrogen and combustion engines. Environ. Innov. Soc. Transit. 2019, 1-15. Available online: https://doi.org/10.1016/j.eist. 2019.03.003 (accessed on 10 December 2019). [CrossRef]

6. Shi, S.; Zhang, H.; Yang, W.; Zhang, Q.; Wang, X. A life-cycle assessment of battery electric and internal combustion engine vehicles: A case in Hebei Province, China. J. Clean. Prod. 2019, 228, 606-618. [CrossRef]

7. Tartakovsky, L.; Sheintuch, M. Fuel reforming in internal combustion engines. Prog. Energy Combust. Sci. 2018, 67, 88-114. [CrossRef]

8. Sindhu, R.; Binod, P.; Pandey, A.; Ankaram, S.; Duan, Y.; Awasthi, M.K. Biofuel Production from Biomass: Towards Sustainable Development. In Current Developments in Biotechnology and Bioengineering; Elsevier, 2019; pp. 79-92. Available online: https://www.elsevier.com/books/current-developments-in-biotechnologyand-bioengineering/larroche/978-0-444-63663-8 (accessed on 10 December 2019).

9. De Souza, L.L.P.; Lora, E.E.S.; Palacio, J.C.E.; Rocha, M.H.; Renó, M.L.G.; Venturini, O.J. Comparative environmental life cycle assessment of conventional vehicles with different fuel options, plug-in hybrid and electric vehicles for a sustainable transportation system in Brazil. J. Clean. Prod. 2018, 203, 444-468. [CrossRef]

10. Sharma, A.; Strezov, V. Life cycle environmental and economic impact assessment of alternative transport fuels and power-train technologies. Energy 2017, 133, 1132-1141. [CrossRef]

11. Bicer, Y.; Dincer, I. Life cycle environmental impact assessments and comparisons of alternative fuels for clean vehicles. Resour. Conserv. Recycl. 2018, 132, 141-157. [CrossRef]

12. Ozbilen, A.; Dincer, I.; Hosseini, M. Comparative Life Cycle Environmental Impact Assessment of Natural Gas and Conventional Vehicles. In Exergetic, Energetic and Environmental Dimensions; Dincer, I., Colpan, C.O., Kizilkan, O., Eds.; Academic Press: Cambridge, MA, USA, 2018; pp. 913-934.

13. Kormos, C.; Axsen, J.; Long, Z.; Goldberg, S. Latent demand for zero-emissions vehicles in Canada (Part 2): Insights from a stated choice experiment. Transp. Res. Part D Transp. Environ. 2019, 67, 685-702. [CrossRef]

14. International Energy Agency. Global EV Outlook 2019 Launched at Clean Energy Ministerial Report. 2019. Available online: https://www.iea.org/news/global-ev-outlook-2019-launched-at-clean-energy-ministerial (accessed on 10 December 2019).

15. Feng, X.; Ouyang, M.; Liu, X.; Lu, L.; Xia, Y.; He, X. Thermal runaway mechanism of lithium ion battery for electric vehicles: A review. Energy Storage Mater. 2018, 10, 246-267. [CrossRef]

16. Adnan, N.; Nordin, S.M.; Rahman, I.; Vasant, P.; Noor, M.A. An overview of electric vehicle technology: A vision towards sustainable transportation. In Intelligent Transportation and Planning; IGI Global: Hershey, PA, USA, 2018; pp. 292-309.

17. Lane, B.W.; Dumortier, J.; Carley, S.; Siddiki, S.; Clark-Sutton, K.; Graham, J.D. All plug-in electric vehicles are not the same: Predictors of preference for a plug-in hybrid versus a battery-electric vehicle. Transp. Res. Part D Transp. Environ. 2018, 65, 1-13. [CrossRef]

18. Liu, Z.; Hao, H.; Cheng, X.; Zhao, F. Critical issues of energy efficient and new energy vehicles development in China. Energy Policy 2018, 115, 92-97. [CrossRef]

19. Wu, Z.; Wang, M.; Zheng, J.; Sun, X.; Zhao, M.; Wang, X. Life cycle greenhouse gas emission reduction potential of battery electric vehicle. J. Clean. Prod. 2018, 190, 462-470. [CrossRef]

20. Islam, H.; Jollands, M.; Setunge, S. Life cycle assessment and life cycle cost implication of residential buildings-A review. Renew. Sustain. Energy Rev. 2015, 42, 129-140. [CrossRef]

21. Babashamsi, P.; Md Yusoff, N.I.; Ceylan, H.; Md Nor, N.G.; Salarzadeh Jenatabadi, H. Evaluation of pavement life cycle cost analysis: Review and analysis. Int. J. Pavement Res. Technol. 2016, 9, 241-254. [CrossRef]

22. Li, J.; Xiao, F.; Zhang, L.; Amirkhanian, S.N. Life cycle assessment and life cycle cost analysis of recycled solid waste materials in highway pavement: A review. J. Clean. Prod. 2019, 233, 1182-1206. [CrossRef]

23. EAFO. European Alternative Fuels Observatory. 2019. Available online: https://www.eafo.eu/countries/ greece/1735/vehicles-and-fleet (accessed on 10 December 2019).

24. Diao, Q.; Sun, W.; Yuan, X.; Li, L.; Zheng, Z. Life-cycle private-cost-based competitiveness analysis of electric vehicles in China considering the intangible cost of traffic policies. Appl. Energy 2016, 178, 567-578. [CrossRef] 
25. Kara, S.; Li, W.; Sadjiva, N. Life Cycle Cost Analysis of Electrical Vehicles in Australia. Procedia CIRP 2017, 61, 767-772. [CrossRef]

26. Lin, C.; Wu, T.; Ou, X.; Zhang, Q.; Zhang, X.; Zhang, X. Life-cycle private costs of hybrid electric vehicles in the current Chinese market. Energy Policy 2013, 55, 501-510. [CrossRef]

27. Pullin, A.S.; Stewart, G.B. Guidelines for systematic review in conservation and environmental management. Conserv. Biol. 2006, 20, 1647-1656. [CrossRef] [PubMed]

28. Costa, D.; Quinteiro, P.; Dias, A.C. A systematic review of life cycle sustainability assessment: Current state, methodological challenges, and implementation issues. Sci. Total Environ. 2019, 686, 774-787. [CrossRef] [PubMed]

29. Fahimnia, B.; Sarkis, J.; Davarzani, H. Green supply chain management: A review and bibliometric analysis. Int. J. Prod. Econ. 2015, 162, 101-114. [CrossRef]

30. Akmal, A.; Podgorodnichenko, N.; Greatbanks, R.; Everett, A.M. Bibliometric analysis of production planning and control (1990-2016). Prod. Plan. Control 2018, 29, 333-351. [CrossRef]

31. Castillo-Vergara, M.; Alvarez-Marin, A.; Placencio-Hidalgo, D. A bibliometric analysis of creativity in the field of business economics. J. Bus. Res. 2018, 85, 1-9. [CrossRef]

32. Sweileh, W.M.; Al-Jabi, S.W.; Zyoud, S.H.; Sawalha, A.F. Outdoor air pollution and respiratory health: A bibliometric analysis of publications in peer-reviewed journals (1900-2017). Multidiscip. Respir. Med. 2018, 13, 1-12. [CrossRef]

33. Ozbay, K.; Jawad, D.; Parker, N.A.; Hussain, S. Life-cycle cost analysis: State of the practice versus state of the art. Transp. Res. Rec. 2004, 1864, 62-70. [CrossRef]

34. Karabasoglu, O.; Michalek, J. Influence of driving patterns on life cycle cost and emissions of hybrid and plug-in electric vehicle powertrains. Energy Policy 2013, 60, 445-461. [CrossRef]

35. Propfe, B.; Redelbach, M.; Santini, D.J.; Friedrich, H. Cost analysis of plug-in hybrid electric vehicles including maintenance \& repair costs and resale values. World Electr. Veh. J. 2012, 5, 886-895.

36. Freire, F; Marques, P. Electric vehicles in Portugal: An integrated energy, greenhouse gas and cost life-cycle analysis. In Proceedings of the 2012 IEEE International Symposium on Sustainable Systems and Technology (ISSST), Boston, MA, USA, 16-18 May 2012; pp. 1-6.

37. Wong, Y.S.; Lu, W.F.; Wang, Z. Life cycle cost analysis of different vehicle technologies in Singapore. World Electr. Veh. J. 2011, 4, 912-920. [CrossRef]

38. Lajunen, A. Energy consumption and cost-benefit analysis of hybrid and electric city buses. Transp. Res. Part C Emerg. Technol. 2014, 38, 1-15. [CrossRef]

39. Sen, B.; Ercan, T.; Tatari, O. Does a battery-electric truck make a difference?-Life cycle emissions, costs, and externality analysis of alternative fuel-powered Class 8 heavy-duty trucks in the United States. J. Clean. Prod. 2017, 141, 110-121. [CrossRef]

40. Zhao, X.; Doering, O.C.; Tyner, W.E. The economic competitiveness and emissions of battery electric vehicles in China. Appl. Energy 2015, 156, 666-675. [CrossRef]

41. Noori, M.; Gardner, S.; Tatari, O. Electric vehicle cost, emissions, and water footprint in the United States: Development of a regional optimization model. Energy 2015, 89, 610-625. [CrossRef]

42. Hao, H.; Cheng, X.; Liu, Z.; Zhao, F. Electric vehicles for greenhouse gas reduction in China: A cost-effectiveness analysis. Transp. Res. Part D Transp. Environ. 2017, 56, 68-84. [CrossRef]

43. Jacobs, W.; Hodkiewicz, M.R.; Bräunl, T. A Cost-Benefit Analysis of Electric Loaders to Reduce Diesel Emissions in Underground Hard Rock Mines. IEEE Trans. Ind. Appl. 2015, 51, 2565-2573. [CrossRef]

44. He, Y.; Zhang, Q.; Pang, Y. The development pattern design of Chinese electric vehicles based on the analysis of the critical price of the life cycle cost. Energy Policy 2017, 109, 382-388. [CrossRef]

45. Li, X.; Tan, Y.; Liu, X.; Liao, Q.; Sun, B.; Cao, G.; Li, C.; Yang, X.; Wang, Z. A cost-benefit analysis of V2G electric vehicles supporting peak shaving in Shanghai. Electr. Power Syst. Res. 2020, 179, 106058. [CrossRef]

46. Moon, S.; Lee, D.J. An optimal electric vehicle investment model for consumers using total cost of ownership: A real option approach. Appl. Energy 2019, 253, 113494. [CrossRef]

47. Mitropoulos, L.K.; Prevedouros, P.D.; Kopelias, P. Total cost of ownership and externalities of conventional, hybrid and electric vehicle. Transp. Res. Procedia 2017, 24, 267-274. [CrossRef]

48. Palmer, K.; Tate, J.E.; Wadud, Z.; Nellthorp, J. Total cost of ownership and market share for hybrid and electric vehicles in the UK, US and Japan. Appl. Energy 2018, 209, 108-119. [CrossRef] 
49. Zhang, X.; Liang, Y.; Yu, E.; Rao, R.; Xie, J. Review of electric vehicle policies in China: Content summary and effect analysis. Renew. Sustain. Energy Rev. 2017, 70, 698-714. [CrossRef]

50. Weldu, Y.W. A Societal Life Cycle Costing of Energy Production: The Implications of Environmental Externalities. In Low Carbon Transition-Technical; Silva, V., Ed.; Econ. Policy Assess.; Intechopen: London, UK, 2018; pp. 109-122. [CrossRef]

51. AECOM. Economic Viability of Electric Vehicles; AECOM: Sydney, Australia, 2009. Available online: https://www.environment.nsw.gov.au/resources/climatechange/ElectricVehiclesReport.pdf (accessed on 7 January 2020).

52. Bakker, D. Battery Electric Vehicles: Performance, CO2 Emissions, Lifecycle Costs and Advanced Battery Technology Development; University of Utrcht: Utrecht, The Netherlands, 2010.

53. Crist, P. Electric Vehicles Revisited: Costs, Subsidies and Prospects. In International Transport Forum Discussion Papers; OECD iLibrary, 2012; Available online: https://doi.org/10.1787/5k8zvv7h9lq7-en (accessed on 7 January 2020).

54. EPRI. Total Cost of Ownership Model for Current Plug-in Electric Vehicles; EPRI: California, CA, USA, 2013.

55. Bascur, J.P.; van Eck, N.J.; Waltman, L. An interactive visual tool for scientific literature search: Proposal and algorithmic specification. CEUR Workshop Proc. 2019, 2345, 76-87.

56. Zhou, X.; Zou, L.; Ma, Y.; Gao, Z.; Wu, Y.; Yin, J.; Xu, X. The current research on electric vehicle. In Proceedings of the 2016 Chinese Control and Decision Conference (CCDC), Yinchuan, China, 28-30 May 2016; pp. 5190-5194. [CrossRef]

57. Korosec, K. GM, LG Chem to invest $\$ 2.3$ billion in EV battery joint venture. Techcrunch 2019, 3. Available online: https://techcrunch.com/2019/12/05/gm-lg-chem-to-invest-2-3-billion-to-in-ev-battery-joint-venture/ (accessed on 7 January 2020).

58. International Energy Agency. Policies and Legislation on Hybrid and Electric Vehicles. Hybrid Electr Veh Technol Collab Program. 2020. Available online: http://www.ieahev.org/ (accessed on 10 December 2019).

(C) 2020 by the authors. Licensee MDPI, Basel, Switzerland. This article is an open access article distributed under the terms and conditions of the Creative Commons Attribution (CC BY) license (http://creativecommons.org/licenses/by/4.0/). 